\title{
IMPLEMENTASI METODE ANP DAN BCA DALAM PEMILIHAN KAPAL SATROL LANTAMAL I GUNA MENDUKUNG TUGAS F1QR DI SELAT MALAKA
}

\author{
Didik Wahyu Cahyono ${ }^{1)}$, Rubiyantoro Murniawan ${ }^{2)}$, Udisubakti Ciptomulyono ${ }^{3)}$ \\ 1) Perwira Siswa Sekolah Staf dan Komando TNI AL tahun 2020, Jakarta \\ ${ }^{2)}$ Kepala Departemen Strategi Sekolah Staf dan Komando TNI AL, Jakarta \\ 3) Guru Besar Institut Teknologi Sepuluh November, Surabaya \\ Sekolah Staf dan Komando TNI Angkatan Laut \\ Jalan Ciledug Raya No 2 Cipulir, Kebayoran Lama, Jakarta Selatan \\ Email:didik.cahyono79@gmail.com
}

\begin{abstract}
Abstrak
Dalam rangka menjaga kedaulatan hukum negara Indonesia di selat Malaka, Komando Armada RI I membentuk satuan reaksi cepat yang lebih dikenal dengan Fleet One Quick Response (F1QR). Dalam pelaksanaan tugas operasi di selat Malaka FIQR dibawah komando wilayah Lantamal I Belawan. Agar terwujudnya keberhasilan tugas F1QR ini, dibutuhkan kekuatan unsur Satrol yang maksimal dalam melaksanakan operasi di laut. Saat ini kondisi unsur Satrol Lantamal I belawan masih terbatas, baik dalam kualitas maupun kuantitas, hanya beberapa unsur yang mampu beroperasi sampai ke Selat Malaka dalam mendukung tugas FlQR. Sehingga sangat diperlukan penambahan ataupun peremajaan unsur Satrol Lantamal I yang efektif dalam mendukung tugas F1QR. Penelitian ini menggunakan metode ANP dan BCA dalam pemilihan kelas kapal Satrol di Lantamal I, serta didukung wawancara kepada stage holder guna memberikan data pendukung melalui metode triangulasi. Penelitian ini mendapatkan hasil akhir bahwasannya kapal Satrol Kelas Torani memiliki nilai keuntungan yang lebih tinggi dibandingkan dengan kapal Satrol Kelas Sigalu, Kelas Tarihu dan kelas Krait, sehingga layak untuk diprioritaskan menjadi kapal Satrol Lantamal I guna mendukung tugas F1QR.
\end{abstract}

Kata kunci: F1QR, Kapal Satrol, Lantamal I, ANP, BCA.

\begin{abstract}
In order to maintain the legal sovereignty of the Indonesian state in the Malacca Strait, the RI Fleet Command I formed a rapid reaction unit better known as the Fleet One Quick Response (F1QR). In carrying out operations in the Strait of Malacca F1QR under the command of the Lantamal I Belawan region. In order for the success of this FIQR task to be realized, the maximum strength of Patrol ship is needed in carrying out operations at sea. Currently, the Patrol ship of Lantamal I are still limited, both in quality and quantity, only a few elements are able to operate up to the Malacca Strait to support F1QR tasks. So it is necessary to add or rejuvenate elements of the Patrol Ship Lantamal I which are effective in supporting the F1QR task. This study used the ANP and BCA methods in selecting the class of Patrol ships at Lantamal I, and was supported by interviews with stageholders to provide supporting data through the triangulation method. This research finds the final result that the Torani Class ships have a higher profit value compared to the Sigalu Class, Tarihu Class and Krait Satrol ships, so that they deserve to be prioritized as a Lantamal I Patrol ship to support F1QR tasks.
\end{abstract}

Keywords: FlQR, Patrol ship, Lantamal I, ANP, BCA.

\section{PENDAHULUAN}

Di dalam UUD 1945 menyatakan bahwa Pemerintah berkewajiban menyelenggarakan upaya-upaya pertahanan negara dari semua bentuk ancaman, baik itu ancaman dari dalam negeri maupun dari luar negeri. Ancaman ini bisa berupa ancaman militer maupun non militer. Dalam menghadapi bentuk ancaman ini diperlukan komponen kekuatan pertahanan negara. Salah satu komponen kekuatan pertahanan negara yang dimiliki bangsa Indonesia adalah TNI Angkatan Laut. TNI Angkatan laut merupakan bagian utama dari komponen kekuatan maritim yang merupakan bagian integral dari TNI. Peran TNI Angkatan Laut sebagai alat negara melaksanakan 
tugasnya sesuai kebijakan politik negara. Berdasarkan Undang Undang Republik Indonesia nomor 34 Tahun 2004 tentang Tentara Nasional Indonesia bahwa TNI Angkatan Laut memiliki tugas yaitu melaksanakan tugas TNI matra laut di bidang pertahanan, menegakkan hukum dan menjaga keamanan laut yurisdiksi nasional sesuai dengan ketentuan hukum nasional dan hukum internasional yang telah di ratifikasi, melaksanakan tugas diplomasi angkatan laut dalam rangka mendukung kebijakan politik luar negeri yang ditetapkan oleh pemerintah, melaksanakan tugas TNI dalam pembangunan dan pengembangan kekuatan matra laut, dan melaksanakan pemberdayaan wilayah pertahanan laut. TNI Angkatan Laut ikut berperan aktif melaksanakan penegakkan hukum dan menjaga keamanan di wilayah laut yurisdiksi Indonesia.

Wilayah laut Indonesia yang masih sering terjadinya pelanggaran hukum ataupun tindak kejahatan adalah di selat Malaka, baik itu berupa pelanggaran IUU fishing, pelanggaran wilayah, penyelundupan, imigran illegal serta pembajakan dan perampokan. Hal ini karena selat Malaka merupakan jalur perdagangan internasional yang paling padat di Indonesia. Selat Malaka ini juga merupakan salah satu pusat lalu lintas pelayaran terpadat di dunia, sekitar 200 kapal melintas setiap harinya. Dalam rangka menjaga kedaulatan hukum negara Indonesia di selat Malaka ini, Komando Armada RI I membentuk satuan reaksi cepat yang lebih dikenal dengan Fleet One Quick Response atau disingkat F1QR. F1QR sebelumnya di kenal dengan sebutan Western Fleet Quick Response (WFQR). Sejak dikeluarkannya Keputusan Presiden nomor 12 Tahun 2018 Pasal 7 tentang pembentukan dan perubahan nama Koarmabar berubah menjadi Koarmada I. Sehingga nama WFQR berubah dan menyesuaikan menjadi F1QR. Kegiatan F1QR berpedoman kepada Prosedur Tetap yang dikeluarkan oleh Koarmada I, saat itu masih bernama Koarmabar. F1QR merupakan bentuk operasi koarmada I di bawah kendali langsung Koarmada I dengan mengedepankan peran satuan kewilayahan Lantamal I, Lantamal II, Lantamal III, Lantamal IV, dan Lantamal XII, dengan memaksimalkan peran keamanan laut yang di perkuat unsur gelar Guspurla Koarmada I serta Guskamla Koarmada I. Hal tersebut sebagai upaya untuk menciptakan keamanan laut di perairan wilayah Koarmada I yang dilaksanakan oleh Lantamal Jajaran. Dalam pelaksanaan tugas operasi di selat Malaka F1QR dibawah komando wilayah Lantamal I Belawan. Sehingga untuk mendapatkan sistem organisasi tugas yang ideal diperlukan bentuk sinergitas antara satuan kerja yang terdiri atas Satuan Kapal Patroli, Staf Operasi, Staf Intelijen, Tim Intelijen, Satuan Hukum dan Polisi Militer Angkatan Laut Lantamal I. F1QR melaksanakan operasi keamanan laut dalam bentuk aksi cepat dan efisien. Agar terwujudnya keberhasilan tugas F1QR I ini, salah satunya dibutuhkan kekuatan unsur Satrol yang maksimal dalam melaksanakan operasi dilaut.

Kondisi saat ini unsur Satrol Lantamal I Belawan sangat terbatas, baik kualitas maupun kuantitas. Hal ini menja dikan kurangnya kehadiran unsur Satrol Lantamal I Belawan di laut, sehingga pelanggaran ataupun kejahatan di laut masih sering terjadi. Berdasarkan keterbatasan jumlah dan kesiapan unsur Satrol Lantamal I Belawan serta keterbatasan anggaran dan bahan bakar operasional yang ada, dihadapkan dengan tugas dan tanggung jawab dalam mendukung F1QR, maka diperlukan penambahan unsur Satrol Lantamal yang efektif dan efisien. Sehingga untuk mendapatkan pilihan alternatif unsur Satrol Lantamal I yang terbaik, Penulis akan melakukan penelitian mengenai "Analisis Pemilihan Unsur Satrol Lantamal I Belawan Guna Mendukung Tugas Fleet One Quick Response (F1QR) Dengan Metode Analitic Network Process (ANP) dan Benefit Cost Analysis (BCA)." Penelitian ini menggunakan metode ANP, karena adanya kompleksitas kriteria dan hubungan yang tidak independen antar kriteria, sehingga diperlukan metode ini untuk menentukan nilai bobot kriteria dan alternatif dari masing-masing pilihan. Sedangkan metode BCA digunakan untuk analisa benefit dan cost yang akan terjadi sebagai konsekuensi operasional kapal tersebut. Dari 2 metode tersebut sehingga didapatkan pilihan alternatif yang optimal, baik dari segi manfaat operasional maupun biaya/ekonomi. Penelitian sebelumnya dilakukan oleh Iwan (2019) dengan judul "Aplikasi Metode MCDM AHP Dan BCA - Aspek Sensor, Weapon, Command Untuk Penetapan KRI Misi MTF Pada KRI Kelas Diponegoro Dan KRI Kelas Bung Tomo", yang membahas tentang pemilihan jenis KRI yang efektif untuk misi MTF PBB. Penelitian ini menginspirasi peneliti untuk menggunakan metode ANP dan BCA pada obyek yang berbeda, dengan adanya hubungan yang tidak 
independen antar kriteria untuk mendapatkan keputusan yang efektif dalam pemilihan unsur Satrol Lantamal I Belawan.

\section{DASAR TEORI}

Dalam penelitian ini menggunakan teori utama dan teori pendukung untuk membahas unsur Satrol yang paling sesuai dioperasikan di Lantamal I Belawan guna mendukung tugas F1QR. Adapun teori utama yang digunakan adalah teori Trinitas Angkatan Laut dan teori pendukungnya adalah teori Sea Power dan teori Efektivitas. Sedangkan metode yang digunakan dalam penelitian ini adalah Analytic Network Process (ANP) dan Benefit Cost Analysis (BCA).

Dalam bukunya yang berjudul "Navies and Foreign Policy" dikatakan bahwa angkatan laut secara universal mempunyai tiga peran dalam melaksanakan tugasnya. Angkatan laut sebagai bagian dari kekuatan nasional, sepanjang usia pengabdiannya lebih banyak melakukan operasi selain perang, hal ini dimungkinkan karena peran universal angkatan laut yang mencakup peran militer, diplomasi dan polisionil. Penambahan dan penentuan jenis unsur Satrol Latamal I Belawan adalah merupakan salah satu bentuk kegiatan untuk memperkuat peran TNI Angkatan Laut, baik itu sebagai peran Militer, Polisionil maupun Diplomasi. Dengan penambahan dan penentuan jenis unsur Satrol yang sesuai, maka diharapkan kekuatan militer Satrol Lantamal I menjadi meningkat dan juga kemampuan penegakkan hukum dilaut semakin kuat serta sarana untuk berdiplomasi lebih banyak.

Teori Sea Power ini dibuat oleh ahli strategi Angkatan Laut Amerika Alfred Thayer Mahan (1660-1783). Dalam bukunya "The Influence of Sea Power Upon History" (1890), menyebutkan bahwa untuk menjadikan bangsa yang besar harus dapat menguasai kepentingankepentingannya di laut dan membutuhkan Angkatan Laut yang kuat untuk melindungi dan meningkatkan kepentingan kepentingannya yang lebih luas lagi. Implementasi dari teori Sea Power dalam pelaksanaan penelitian ini adalah dengan adanya penentuan dan penambahan unsur Satrol Lantamal I Belawan maka kekuatan TNI Angkatan Laut menjadi lebih kuat. Hal ini dapat menjadikan deterrence effect bagi pihak-pihak yang berniat menggangu atau menguasai wilayah Indonesia. Selain itu dengan penambahan unsur Satrol Lantamal I Belawan diharapkan akan menambah kehadirannya di laut, sehingga kepentingan-kepentingan yang ada dilaut seperti perdagangan, transportasi dan lain-lain menjadi lebih aman.

David J. Lawless di dalam Teori Efektivitasnya membagi "efektivitas" menjadi tiga tingkatan, yaitu efektivitas Individu, efektivitas kelompok dan efektivitas organisasi, sebagaimana yang ditulis dalam bukunya Effective Management: Social Psychological Approach. Teori Efektivitas sangat terkait pemilihan unsur Satrol Lantamal I Belawan dalam mendukung tugas F1QR. Dalam hal ini terkait dengan efektivitas unsur Satrol dalam melaksanakan operasi keamanan laut di wilayah kerjanya sesuai dengan fungsi Satrol Lantamal. Pada penelitian ini tingkat efektivitas unsur Satrol akan diukur dengan tingkat rasio Benefit-Cost yang didapatkan pada seluruh komponen. Diharapkan nilai rasio atau perbandingan antara Benefit-Cost tinggi, sehingga akan semakin tinggi nilai efektivitas dari gabungan komponen tersebut. Penilaian tersebut akan diukur dengan dihadapkan pada kriteria-kriteria pemilihan suatu kapal. Dengan demikian diharapkan akan lebih meyakinkan Pimpinan TNI Angkatan Laut dalam menentukan jenis unsur Satrol yang paling sesuai di Lantamal I Belawan ataupun di seluruh wilayah Indonesia.

ANP adalah generalisasi dari AHP dimana beberapa faktor dipertimbangkan secara langsung, terdapat sifat ketergantungan dan feedback, dan memerlukan pertukaran numerik untuk mendapatkan kesimpulan sintesis. Perbedaan di antara AHP dan ANP adalah AHP memiliki struktur hierarki sedangkan ANP memiliki struktur networks atau jaringan. ANP merupakan sebuah metode yang menghasilkan kerangka untuk mengatasi permasalahan pengambil keputusan tanpa melibatkan asumsi-asumsi yang berkaitan dengan independensi antara level elemen yang lebih tinggi dengan yang lemah dan independensi dari elemen-elemen dalam satu level. ANP melibatkan hubungan secara hierarkis tetapi kontrol hierarki ini tidak membutuhkan struktur baku seperti pada AHP sehingga mampu menangani hubungan yang kompleks antara level-level keputusan dengan atribut-atribut. ANP ini memodelkan sistem dengan feedback dan 
sistem dimana satu level mungkin mendominasi maupun didominasi, baik secara langsung maupun tidak langsung oleh level lainnya.

Benefit Cost Analysis adalah cara praktis untuk menaksir kemanfaatan proyek, di mana untuk hal ini diperlukan tinjauan yang panjang dan luas. Dengan kata lain, diperlukan analisa dan evaluasi dari berbagai sudut pandang yang relevan terhadap ongkos-ongkos maupun manfaat yang disumbangkannya. $B / C$ Analysis biasanya dilakukan dengan melihat rasio antara manfaat dari suatu proyek pada masyarakat umum terhadap ongkos-ongkos yang dikeluarkan. Secara matematis hal ini diformulasikan sebagai berikut:

$$
B / C=\frac{\text { Manfaat }}{\text { Ongkos }}
$$

Suatu proyek dikatakan layak atau bisa dilaksanakan apabila perbandingan antara manfaat terhadap biaya yang dibutuhkannya lebih besar dari satu. Pendekatan menggunakan $B / C$ Analysis pada ANP sama dengan pendekatan B/C Analysis pada umumnya, jika pada ANP yang akan dilakukan perbandingan adalah pioritas keunggulan dan prioritas harga, sehingga yang akan dipilih adalah nilai perbandingan dengan nilai terbesar.

\section{METODOLOGI PENELITIAN}

Metodologi yang digunakan dalam penelitian ini adalah mixed method dengan menggunakan desain concurrent embedded, karena waktu yang digunakan dalam penelitian terbatas. Desain concurrent embedded adalah model penelitian yang menggabungkan antara metode penelitian kualitatif dan kuantitatif dengan cara mencampur kedua metode tersebut secara tidak berimbang. Penerapan metode concurrent embedded dalam penelitian ini yaitu dengan menggunakan ANP sebagai metode kuantitatif untuk mendapatkan nilai perbandingan dari alternatif yang ada dan metode BCA digunakan untuk menghitung perbandingan faktor manfaat dan faktor biaya guna mendapatkan penilaian efektif dan efisien. Sedangkan metode kualitatif digunakan untuk mengukur permasalahan kompleks melalui jaringan yang teruji konsistensinya untuk mendapatkan kesimpulan yang objektif. Adapun data kualitatif yang kami kumpulkan meliputi data hasil wawancara kepada subjek penelitian terkait data primer meliputi beberapa hal antara lain bagaimana kondisi dan kemampuan unsur Satrol Lantamal I belawan dalam mendukung pelaksanaan tugas F1QR, bagaimana perbandingan kemampuan operasional dari alternatif kapal Satrol saat ini, bagaimana perbandingan spesifikasi teknis dari alternatif kapal Satrol saat ini, bagaimana perbandingan proses pengadaan dari tiap alternatif kapal Satrol tersebut, bagaimana dengan perbandingan logistik operasionalnya, bagaimanana rencana pengadaan jenis unsur Satrol ke depannya.

Adapun tahapan pengolahan data dengan metode ANP yaitu; tahap pemodelan, tahap pembobotan, tahap penentuan bobot keterkaitan antar node dan cluster, tahap cluster matrix dan unweighted supermatrix, tahap hasil bobot prioritas dari pembobotan keterkaitan antar cluster disusun pada cluster matrix, tahap weighted supermatrix, tahap limiting matrix dan tahap normalisasi limiting matrix.

\section{HASIL DAN PEMBAHASAN}

Penelitian dilaksanakan di Lantamal I Belawan, Koarmada I dan Mabesal. Adapun pilihan alternatif unsur Satrol yang Lantamal I yang digunakan dalam penelitian ini adalah unsur Satrol yang mampu beroperasi sampai ke Selat Malaka, yaitu yang mempunyai panjang unsur di atas 30 meter. Unsur alternatif Satrol yang masuk dalam kriteria ini adalah Sigalu class, Tarihu class, Krait class dan Torani class.

a. Pengolahan Data dengan ANP

Langkah pertama pada proses metode ANP adalah pembuatan jaringan dari kriteria, subkriteria dan alternatif yang telah ditentukan. Setelah model terbuat maka langkah selanjutnya adalah menggambarkan model tersebut ke dalam Software Super Decision. Pembuatan model 
pada Software Super Decision dibagi dengan membagi menjadi tiga sesuai dengan jumlah kriteria di antaranya Operational Requirements (Opsreq), Technical Specification (Spektek), dan Khusus. Berikut ini merupakan model Network ANP yang telah digambar secara manual dan hasil gambar model jaringan pada Software Super Decision.
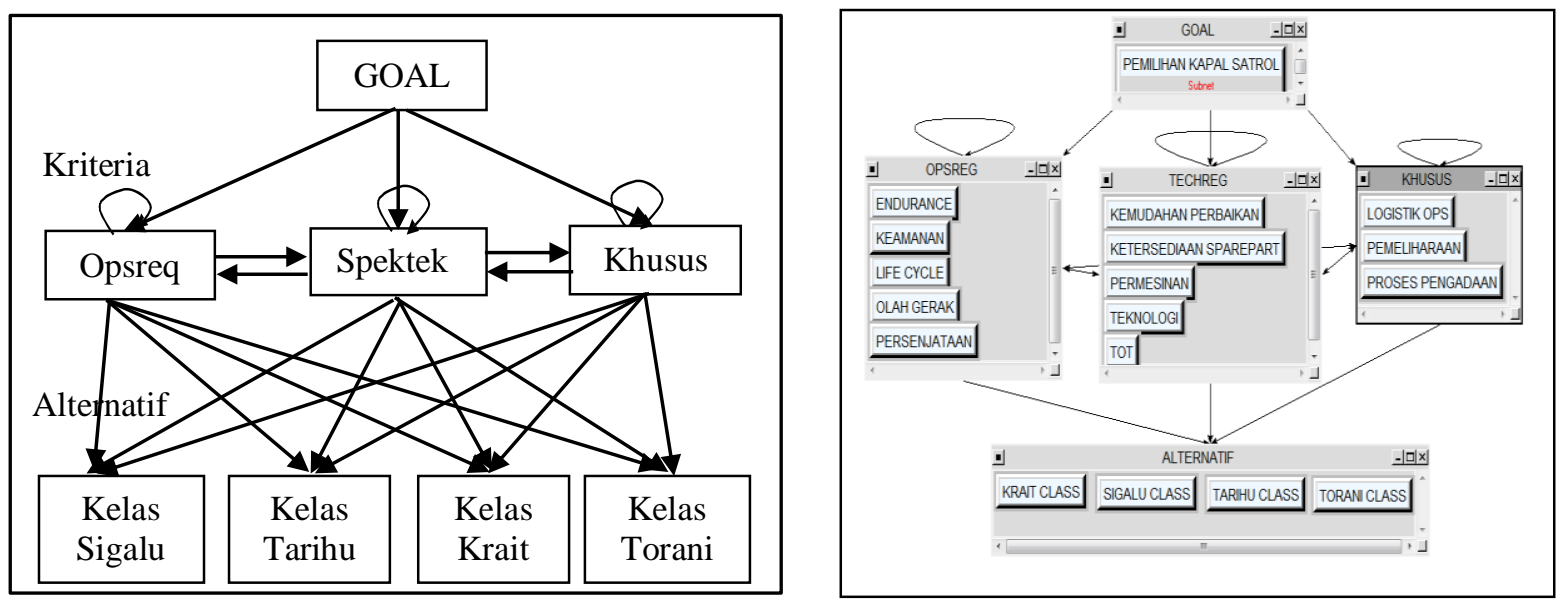

Gambar 1. Model Network ANP

Pada gambar 1 terlihat model Jaringan ANP yang digambarkan dengan tanda panah yang mengarah dari satu kriteria ke kriteria yang lain. Tanda panah pada gambar tersebut dapat diartikan sebagai pengaruh sedangkan pangkal tanda panah tersebut merupakan kriteria/kluster yang memengaruhi. Hal ini dapat dicontohkan seperti pada Kriteria Opsreq berdasarkan gambar tersebut dipengaruhi oleh kriteria Spektek dan Khusus, demikian juga sebaliknya tiap kriteria saling memengaruhi. Hal tersebut juga berlaku pada sub kriteria.

Langkah kedua dalam proses ANP adalah menghitung pairwise comparison pada kriteria, sub kriteria dan alternatif pilihan jenis kapal Satrol. Dalam mendapatkan nilai pairwise comparison pada kriteria, sub kriteria dan alternatif berdasarkan pada hubungan innerdefendence dan outerdefendence. Dalam penelitian ini, peneliti mengasumsikan bahwa semua kriteria dan sub kriteria yang ada mempunyai hubungan yang saling memengaruhi baik itu innerdefendence dan outerdefendence, sehingga pembuatan kuisioner menggambarkan semua hubungan dari masing-masing kriteria, sub kriteria dan alternatif yang ada. Kuesioner diberikan kepada expert yang berhubungan dengan unsur Satrol Lantamal I akan berisi perbandingan penilaian terhadap kriteria, sub kriteria dan alternatif yang akan dipilih berdasarkan angka perbandingan berpasangan dengan skala 1-9. Hasil kuesioner dari masing-masing expert tersebut selanjutkan akan diolah untuk menghasilkan keputusan yang tepat dalam pemilihan dan pengembangan unsur Satrol Lantamal I.

Langkah ketiga dalam proses ANP adalah menghitung nilai prioritas kriteria, sub kriteria dan alternatif. Data hasil kuesioner yang diperoleh dari para expert selanjutnya diinput terlebih dahulu pada Software Super Decision untuk mengetahui nilai konsistensi dari masing-masing expert. Setelah seluruh data dipastikan konsisten maka langkah selanjutnya adalah menyatukan nilai dari ke sepuluh expert menjadi satu menggunakan tools Micorsoft Excel dengan menggunakan nilai Geomean. Rumus rata-rata Geometrik adalah sebagai berikut:

$$
a=\sqrt[n]{a 1 * a 2 * a n}
$$

Keterangan:

$$
\begin{array}{cl}
a & : \text { Nilai Geomean } \\
a 1 & : \text { Responden ke-1 } \\
a 2 & : \text { Responden ke-2 } \\
a n & : \text { Responden ke-n } \\
n & : \text { Jumlah responden }
\end{array}
$$


Perhitungan geomean akan menghasilkan data kuesioner dari para expert tersebut menjadi satu nilai yang akan diolah oleh peneliti. Langkah selanjutnya melaksanakan input data nilai geomean tersebut ke dalam Software Super Decision sambil memeriksa nilai konsistensi masing-masing perbandingan berpasangan baik kriteria maupun sub kriteria. Nilai konsistensi tiap hubungan kriteria dan sub kriteria harus kurang dari 0,1 .

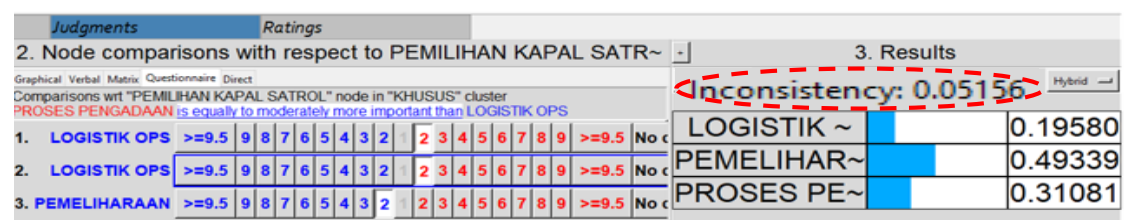

Gambar 2. Pengecekan Nilai Konsistensi

Setelah proses perhitungan konsistensi maka langkah selanjutnya adalah proses perhitungan nilai bobot prioritas baik pada kriteria maupun sub kriteria. Hasil bobot prioritas nantinya akan menampilkan secara keseluruhan hasil perhitungan baik prioritas alternatif kapal Satrol, prioritas kriteria serta prioritas sub kriteria pada Software Super Decision. Berikut ini nilai bobot perhitungan prioritas tersebut.

\begin{tabular}{|c|c|c|c|c|}
\hline \multirow{2}{*}{\multicolumn{5}{|c|}{$\begin{array}{l}\text { Main Network: TESIS.sdmod: ratings: Priorities } \\
\text { Here are the priorities. }\end{array}$}} \\
\hline \multicolumn{2}{|c|}{ Here are the priorities. } & & & \\
\hline \multirow{2}{*}{\begin{tabular}{|l|} 
Icon \\
No Icon
\end{tabular}} & \multirow{2}{*}{$\begin{array}{r}\text { Name } \\
\text { KRAIT CLASS }\end{array}$} & \multicolumn{3}{|c|}{$\sqrt{\text { Normalized by Cluster } \sqrt{\text { Limiting }}}$} \\
\hline & & I & 0.27041 & 0.067601 \\
\hline No Icon & SIGALU CLASS & I & 0.09972 & 0.024931 \\
\hline No Icon & TARIHU CLASS & I & 0.09014 & 0.022536 \\
\hline No Icon & TORANI CLASS & I & 0.53973 & 0.134931 \\
\hline No Icon & PEMILIHAN KAPAL SATROL & I & 0.00000 & 0.000000 \\
\hline No Icon & LOGISTIK OPS & & 0.32054 & 0.080135 \\
\hline No Icon & PEMELIHARAAN & I & 0.34213 & 0.085532 \\
\hline No Icon & PROSES PENGADAAN & & 0.33733 & $\longdiv { 0 . 0 8 4 3 3 3 }$ \\
\hline No Icon & ENDURANCE & & 0.15050 & 0.037624 \\
\hline No Icon & KEAMANAN & & 0.35423 & $\longdiv { 0 . 0 8 8 5 5 8 }$ \\
\hline No Icon & LIFE CYCLE & & 0.17581 & 0.043953 \\
\hline No Icon & OLAH GERAK & I & 0.20835 & $\longdiv { 0 . 0 5 2 0 8 7 }$ \\
\hline No Icon & PERSENJATAAN & I & 0.11111 & 0.027778 \\
\hline No Icon & KEMUDAHAN PERBAIKAN & I & 0.20478 & 0.051194 \\
\hline No Icon & KETERSEDIAAN SPAREPART & I & 0.23495 & 0.058737 \\
\hline No Icon & PERMESINAN & & 0.28982 & 0.072454 \\
\hline No Icon & TEKNOLOGI & I & 0.14537 & 0.036342 \\
\hline No Icon & ТОТ & & 0.12509 & 0.031273 \\
\hline \multicolumn{5}{|c|}{\begin{tabular}{l|l|} 
Okay & Copy Values \\
\end{tabular}} \\
\hline
\end{tabular}

\section{Gambar 3. Nilai Bobot Prioritas}

Berdasarkan nilai bobot prioritas pada gambar 3. maka dapat disimpulkan bahwa prioritas alternatif pada hasil perhitungan Software Super Decision berturut-turut dari prioritas pertama adalah kapal kelas Torani dengan nilai 0,53973, kelas Krait dengan nilai 0,27041, kelas Sigalu dengan nilai 0,09972 dan kelas Tarihu berada diurutan terakhir dengan nilai 0,09014. Sedangkan untuk nilai prioritas kriteria mulai dari prioritas pertama adalah kriteria Keamanan dengan nilai 0,35423 , kriteria kedua adalah Pemeliharaan dengan nilai 0,34213 dan prioritas ketiga adalah kriteria Proses Pengadaan dengan nilai 0,33733.

Langkah selanjutnya adalah dengan melakukan analisa sensitivitas yang mana langkah ini dilakukan untuk mengetahui tingkat stabilitas dari alternatif yang terpilih dihadapkan dengan kondisi dari kriteria yang ada. Hal ini dilakukan juga untuk mengantisipasi terjadi perubahanperubahan yang mungkin terjadi pada kriteria sehingga apabila nilai prioritas tersebut sudah stabil maka kemungkinan perubahan pada alternatif juga akan kecil. Berikut adalah hasil analisis sensitivitas penghitungan data dari pemilihan unsur Satrol Lantamal I Belawan. 


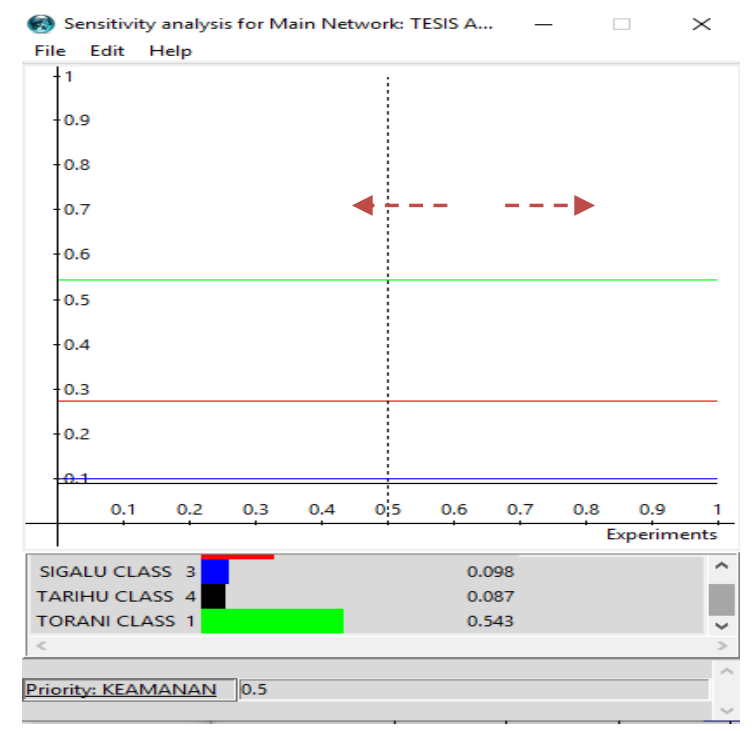

Gambar 4. Analisa Sensitivitas

Gambar 4 merupakan diagram sensitivitas salah satu sub kriteria (keamanan) terhadap alternatif pilihan jenis kapal Satrol. Pemeriksanaan nilai sensitivitas dilaksanakan pada Software Super Decision dengan cara merubah nilai pada garis vertikal pada tampilan analisa senstivitas. Apabila dari masing-masing alternatif berupa garis horizontal (berwarna merah, hijau, hitam dan biru) tidak menunjukkan perubahan, maka hal itu menandakan bahwa sensitivitas pada bagian tersebut adalah stabil. Berdasarkan diagram tersebut, berapapun nilai keamanan ternyata rangking alternatif jenis jenis kapal Satrol tidak berubah. Hal ini menunjukkan bahwa hasil akhir dari model pemilihan ini sangat stabil.

b. Pengolahan Data dengan Benefit Cost Analysis (BCA).

Pengaplikasian BCA berkaitan erat dengan tiga hal penting dan saling berhubungan yaitu Manfaat (Benefit) sebagai domain bisnis yang merupakan wujud penurunan biaya dan atau peningkatan kinerja atau revenue, Biaya (Cost) sebagai dominan teknologi yaitu beberapa biaya tetap dan biaya variable yang diperlukan untuk membangun sistem, serta Nilai (Value) yaitu manfaat yang diperoleh oleh suatu pihak atas keberlangsungan kegiatan.

Pada penelitian ini menggolongkan seluruh kriteria yang ada dalam penentuan jenis unsur Satrol Lantamal I yang berjumlah 13 sub kriteria tersebut ke dalam dua kelompok faktor, yaitu faktor Manfaat dan faktor Biaya. Faktor Manfaat didefinisikan sebagai seluruh faktor yang dapat memberikan pengaruh positif dan hasil yang baik terhadap pemilihan unsur Satrol Lantamal I. Sedangkan faktor Biaya merupakan segala sesuatu yang membutuhkan biaya, waktu dan tenaga yang lebih guna memenuhinya, sehingga dapat mendukung operasional unsur Satrol dengan baik. Hasil nilai pembobotan tiap alternatif dari faktor Manfaat akan diperbandingkan dengan hasilnya dari faktor Biaya, sehingga akan diketahui bobot keuntungan atau manfaat dari masing-masing Alternatif unsur Satrol yang ada. Penggolongan kriteria dalam pemilihan unsur Satrol Lantamal I ke dalam kelompok faktor Manfaat dan faktor Biaya, serta penyusunan diagram ANP dari masing-masing faktor Manfaat dan Biaya. 
Tabel 1. Penggolongan Faktor Manfaat dan Biaya

\begin{tabular}{|c|l|c|}
\hline No & Kriteria Pemilihan & Kelompok (Faktor) \\
\hline 1 & Keamanan (KAM) & Manfaat \\
\hline 2 & Olah gerak (OGK) & Manfaat \\
\hline 3 & Persenjataan (SEN) & Manfaat \\
\hline 4 & Life Cycle (LCE) & Biaya \\
\hline 5 & Endurance (EDE) & Manfaat \\
\hline 6 & Teknologi (TEK) & Manfaat \\
\hline 7 & Permesinan (SIN) & Manfaat \\
\hline 8 & Transfer of Technology (TOT) & Biaya \\
\hline 9 & Kemudahan Perbaikan (KPN) & Biaya \\
\hline 10 & Persediaan Spare Part (PSP) & Biaya \\
\hline 11 & Proses Pengadaan (ADA) & Biaya \\
\hline 12 & Logistik Operasional (LOG) & Biaya \\
\hline 13 & Pemeliharaan (HAR) & \\
\hline
\end{tabular}

Bagan jaringan ANP yang dibentuk dari faktor Manfaat dan Biaya adalah seperti pada gambar 5.
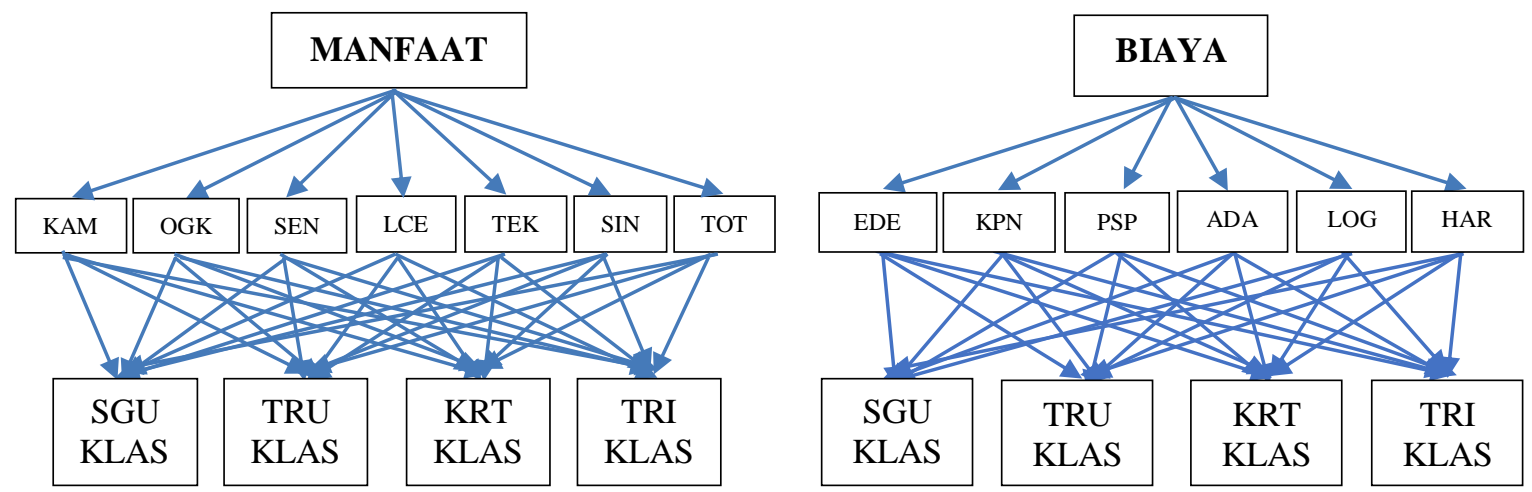

Gambar 5. Model Network kelompok Manfaat dan Biaya

Tahapan penelitian selanjutnya pada BCA yaitu mengolah data keseluruhan menggunakan metode ANP dengan sistem jaringan dari faktor Manfaat dan faktor Biaya. Peneliti akan melaksanakan pengolahan data sesuai dengan tahapan yang ada dalam metode ANP yang telah peneliti lakukan sebelumnya. Peneliti pun akan menggunakan program super decision sebagai tools dalam pengolahan data ANP. Hasil bobot prioritas menampilkan secara keseluruhan prioritas alternatif dan kriteria yang ada, baik pada faktor manfaat maupun faktor biaya. Pada akhirnya dari software super decision didapatkan Nilai Bobot Prioritas/Total Priority Value (TPV) untuk Faktor Biaya dan Faktor Manfaat dari masing-masing alternatif kapal Satrol Lantamal I Belawan sebagai berikut:

Tabel 2. Nilai Bobot Prioritas dari Faktor Manfaat dan Biaya

\begin{tabular}{|c|l|c|c|}
\hline \multirow{2}{*}{ NO } & \multirow{2}{*}{ JENIS KAPAL } & \multicolumn{2}{|c|}{ TOTAL PRIORITY VALUE } \\
\cline { 3 - 4 } & & MANFAAT & BIAYA \\
\hline 1 & Sigalu Klas & 0,09685 & 0,11509 \\
\hline 2 & Tarihu Klas & 0,05577 & 0,06313 \\
\hline 3 & Krait Klas & 0,30658 & 0,28283 \\
\hline 4 & Torani Klas & 0,54079 & 0,53895 \\
\hline
\end{tabular}

BCR merupakan salah satu bentuk perhitungan BCA yang digunakan untuk menentukan kelayakan suatu investasi baik berupa usaha maupun proyek, melalui perbandingan (rasio) antara Benefit dan Cost. Teknik perhitungan BCR ini menekankan pada perhitungan faktor Manfaat (benefit) dan Biaya (cost). Nilai perbandingan Faktor Biaya yang diambil dari para responden 
merupakan nilai perbandingan keterkaitan kemampuan positif dari kriteria pemilihan unsur Satrol Lantamal I tersebut. Sehingga data input nilai TPV masing-masing alternatif unsur Satrol Lantamal I untuk Faktor Biaya yang dimasukkan harus berupa selisih nilai tersebut dengan nilai TPV yang dihasilkan, yaitu dengan rumus 1-nilai TPV.

$$
\mathrm{BCR}=\frac{\text { Nilai } T P V \text { pada Faktor Manfaat }}{1-\text { Nilai } T P V \text { pada Faktor Biaya }}
$$

Sehingga didapatkan:

- Nilai BCR Satrol Kelas Sigalu $=0,11$

- Nilai BCR Satrol Kelas Tarihu $=0,06$

- Nilai BCR Satrol Kelas Krait $=0,43$

- Nilai BCR Satrol Kelas Torani $=1,17$

Didapatkan perhitungan BCA yang dilakukan melalui teknik BCR dimana membandingkan nilai TPV hasil pengelompokan kriteria pemilihan unsur Satrol Lantamal I Belawan ke dalam Faktor Manfaat dan Faktor Biaya mendapatkan hasil unsur Satrol Kelas Torani dapat memberikan manfaat atau keuntungan (nilai BCR 1,17). Sedangkan unsur Satrol lainnya kurang memberikan manfaat/keuntungan (nilai BCR $<1$ ).

\section{KESIMPULAN}

Penelitian ini menghasilkan bahwasanya nilai kapal Satrol Kelas Torani lebih tinggi dari pada alternatif kapal satrol yang lain. Peneliti mendapat kesimpulan tersebut melalui hasil pengolahan menggunakan metode ANP dan BCA yang didapatkan dari para responden di bidangnya sebagai subjek penelitian. Hal tersebut juga diperkuat dengan hasil triangulasi wawancara dari para informan yang merupakan subjek penelitian regulator dalam penentuan unsur Satrol Lantamal I. Hasil triangulasi wawancara menyebutkan bahwasannya kapal Satrol Kelas Torani lebih baik dibandingkan dengan alternatif kapal kelas Satrol yang lainnya. Hal ini disebabkan kapal Satrol Kelas Torani mempunyai olah gerak dan kecepatan yang lebih tinggi serta pemeliharaan yang lebih mudah, dan juga bodi kapal yang lebih besar untuk mampu menjangkau ke Selat Malaka dengan berbagai kondisi cuaca yang terjadi.

\section{Daftar Pustaka}

[1] E. Mishan \& Euston, Cost Benefit Analysis, New York and London: Routledge Taylor \& Francis Group, 2007.

[2] Iwan, Aplikasi Metode MCDM - AHP Dan BCA - Aspek Sensor, Weapon, Command Untuk Penetapan KRI Misi MTF Pada KRI Kelas Diponegoro Dan KRI Kelas Bung Tomo, Seskoal, 2019.

[3] K. Booth, Navies and Foreign Policy, London: Routledge, 1977.

[4] Koarmabar, Prosedur Tetap Respon Cepat Koarmabar (Western Fleet Quick Response), 2015.

[5] Sugiyono, Metode Penelitian Pendidikan, Pendekatan Kuantitatif, Kualitatif dan R\&D, Cet ke-19, Bandung: Alfabeta, 2014.

[6] Stefanus dan Adiyanto, Komando Pengendalian Keamanan dan Keselamatan Laut, Jakarta: Gramedia, 2015.

[7] T. Saaty, Decision Making in Complex Environments: The Analytic Network Process (ANP) for Dependence and Feedback, Pittsburgh, 2016.

[8] U. Ciptomulyono, Paradigma pengambilan Keputusan Multikriteria Dalam Perspektif Pengembangan Projek Dan Industri Yang Berwawasan Lingkungan, ITS Surabaya, 2010. 